\title{
Glucocorticoid effects on chondrogenesis, differentiation and apoptosis in the murine ATDC5 chondrocyte cell line
}

\author{
T Mushtaq $^{1,2}$, C Farquharson ${ }^{2}$, E Seawright ${ }^{2}$ and S F Ahmed ${ }^{1}$ \\ ${ }^{1}$ Department of Child Health, Royal Hospital for Sick Children, Yorkhill, Glasgow G3 8SJ, UK \\ ${ }^{2}$ Department of Integrative Biology, Roslin Institute, Edinburgh EH25 9PS, UK \\ (Requests for offprints should be addressed to C Farquharson; Email: Colin.Farquharson@bbsrc.ac.uk)
}

\begin{abstract}
Glucocorticoids (GC) are used extensively in children and may cause growth retardation, which is in part due to the direct effects of GC on the growth plate. We characterised the ATDC5 chondrocyte cell line, which mimics the in vivo process of longitudinal bone growth, to examine the effects of dexamethasone (Dex) and prednisolone (Pred) during two key time points in the chondrocyte life cycle chondrogenesis and terminal differentiation. Additionally, we studied the potential for recovery following Dex exposure. During chondrogenesis, Dex and Pred exposure at $10^{-8} \mathrm{M}, 10^{-7} \mathrm{M}$ and $10^{-6} \mathrm{M}$ resulted in a significant mean reduction in cell number (28\% vs $20 \%)$, cell proliferation $(27 \%$ vs $24 \%)$ and proteoglycan synthesis (47\% vs $43 \%)$ and increased alkaline phosphatase (ALP) activity (106\% vs 62\%), whereas the incidence of apoptosis was unaltered. Minimal effects were noted during terminal differentiation with both GC although all concentrations
\end{abstract}

of Dex lowered apoptotic cell number. To assess catch-up growth the cells were incubated for a total of 14 days which included $1,3,7,10$ or 14 days exposure to $10^{-6} \mathrm{M}$ Dex, prior to the recovery period. Recovery of proteoglycan synthesis was irreversibly impaired following just one day exposure to Dex. Although cell number showed a similar pattern, significant impairment was only achieved following 14 days exposure. Irreversible changes in ALP activity were only noticed following 10 days exposure to Dex.

In conclusion, GC have maximal effects during chondrogenesis; Dex is more potent than Pred and cells exposed to Dex recover but this may be restricted due to differential effects of GC on specific chondrocyte phenotypes.

Journal of Endocrinology (2002) 175, 705-713

\section{Introduction}

Glucocorticoids (GC) are commonly used as antiinflammatory therapy and in immunosuppressive regimens and it is estimated that $5-10 \%$ of children may require some form of GC therapy at some time in childhood (Warner 1995). The functional effects of steroids on target tissues are difficult to predict and their use is hampered in some individuals more than others because of side-effects such as growth retardation and osteoporosis. Impairment of childhood growth with long-term GC was described almost 50 years ago but more recent studies have shown that altered growth and bone turnover also occur during relatively short periods of GC therapy and that these effects may vary depending on the type of corticosteroid used (Blodget et al. 1956, Crofton et al. 1998, Ahmed et al. 1999, 2002).

At the level of the growth plate, local and systemic factors regulate longitudinal bone growth which involves the differentiation of committed stem cells into proliferating chondrocytes; after a finite number of cell divisions these cells terminally differentiate into the hypertrophic phenotype that deposit a matrix which is mineralised and eventually replaced by bone (Green et al. 1985, Isaksson et al. 1991). GC-induced growth failure may be due to a combination of factors such as a disruption of the growth hormone-insulin-like growth factor-I (GH-IGF-I) axis, a defect in sex steroid action, a disturbance in calcium and phosphate homeostasis as well as direct effects on the growth plate (Crilly et al. 1978, Unterman \& Phillips 1985, Baron et al. 1992, Jux et al. 1998).

Studies in children suggest that growth retardation following a short period of systemic exposure to GC may be followed by a period of catch-up growth and that alternate day therapy may be less adverse for growth (Jabs et al. 1996, Ahmed et al. 1999). Catch-up growth has also been observed following direct injection of GC into the growth plate of rabbits (Baron et al. 1994).

The direct effects of GC on chondrocytes are not clearly understood and previous studies that have examined the effect of GC on primary growth plate chondrocytes have 
Table 1 Primer pairs used for specific gene analysis

\begin{tabular}{|c|c|c|c|}
\hline \multirow[b]{2}{*}{ Gene } & Primer sequence & Cycles & Product size $(b p)$ \\
\hline & & & \\
\hline $18 \mathrm{~S}$ & Unknown, purchased commercially from Ambion & 15 & 488 \\
\hline Collagen type II & TTAGAAAGGGGAGCACAGTCC & 35 & 323 \\
\hline Collagen type $X$ & $\begin{array}{l}\text { CAGAGGAAGCCAGGAAAGC } \\
\text { GGTGTCCAGGACTTCCATAGC }\end{array}$ & 32 & 330 \\
\hline
\end{tabular}

Ambion, Huntingdon, Cambs, UK.

been unable to examine the effect of GC on the different stages of the chondrocyte life cycle due to the heterogeneous mixture of maturational phenotypes (Robson et al. 1998, Koedam et al. 2000). Recently, the murine ATDC5 chondrocyte cell line has been shown to undergo the temporal sequence of events that occur during longitudinal bone growth in vivo and thereby provide a good model to study the molecular mechanisms underlying regulation of endochondral bone formation (Atsumi et al. 1990, Shukunami et al. 1997). In this study, this cell line was used to explore the effects of two commonly used glucocorticoids, dexamethasone (Dex) and prednisolone (Pred), on cell number, proliferation, differentiation and apoptosis at key maturational time points (chondrogenesis and terminal differentiation), within the chondrocyte life cycle. The effect of the GC on the ability of chondrocytes to recover following GC exposure was also studied to assess the potential for catch-up growth.

\section{Materials and Methods}

\section{Chondrocyte cell culture}

The ATDC5 chondrocyte line was obtained from the RIKEN cell bank (Ibaraki, Japan) and maintained as described by Atsumi et al. (1990). Cells were cultured at a density of 12000 cells per $\mathrm{cm}^{2}$ in multi-well plates (Costar, High Wycombe, Bucks, UK) in a maintenance medium of DMEM/Ham's F12 (Invitrogen, Paisley, Strathclyde, UK) supplemented with 5\% FCS (Invitrogen), $10 \mu \mathrm{g} / \mathrm{ml}$ human transferrin and $3 \times 10^{-8} \mathrm{M}$ sodium selenite (Sigma, Poole, Dorset, UK) until confluent (day 6). Thereafter, differentiation was induced by the addition of insulin $(10 \mu \mathrm{g} / \mathrm{ml}$; Sigma $)$ and ascorbic acid $(20 \mu \mathrm{g} / \mathrm{ml})$ to the maintenance medium (differentiation medium). Incubation was at $37{ }^{\circ} \mathrm{C}$ in a humidified atmosphere of $95 \%$ air $/ 5 \% \mathrm{CO}_{2}$ and the medium was changed every second day.

\section{Gene expression}

For the determination of chondrocyte phenotype, cells were grown for up to 20 days as above and RNA was extracted, reverse transcribed and analysed for collagen type II and collagen type X expression at days 6, 8, 10, 13, 15, 17 and 20 by semi-quantitative RT-PCR.

\section{$R N A$ extraction}

Total RNA was extracted from chondrocytes by repeated aspiration through a 25-gauge syringe needle in $1.5 \mathrm{ml}$ Ultraspec (Biotecx, Houston, TX, USA). After extraction with chloroform, RNA in the aqueous phase was precipitated with isopropanol and bound to RNA Tack resin (Biotecx) following the manufacturer's protocol. After washing with 75\% ethanol, the RNA was eluted in $100 \mu \mathrm{l}$ ribonuclease-free water (Houston et al. 1999). In each case the $260 / 280$ ratio was $1 \cdot 9-2 \cdot 0$, confirming the purity of the RNA. All preparations were diluted to a concentration of $50 \mathrm{ng} / \mu \mathrm{l}$ and stored at $-70{ }^{\circ} \mathrm{C}$.

\section{Semiquantative RT-PCR}

Gene expression was analysed by semiquantitative RTPCR (Farquharson et al. 1999, Houston et al. 1999, Jefferies et al. 2000). Aliquots of $500 \mathrm{ng}$ RNA (or an equivalent volume of water as a control) were reverse transcribed in $20-\mu \mathrm{l}$ reactions with $200 \mathrm{ng}$ random hexamers and 200 U Superscript II reverse transcriptase using the Superscript preamplification protocol (Invitrogen). PCR was performed in $20-\mu \mathrm{l}$ reactions containing cDNA equivalent to $10 \mathrm{ng}$ RNA and $200 \mathrm{nM}$ gene-specific primers in $11.1 \times$ PCR buffer (Jefferies et al. 1998) (Table 1). The cycling profile was $1 \mathrm{~min}$ at $92^{\circ} \mathrm{C}$ (first cycle, $2 \mathrm{~min}$ ), $1 \mathrm{~min}$ at $55^{\circ} \mathrm{C}$, and $1 \mathrm{~min}$ at $70^{\circ} \mathrm{C}$. The number of cycles performed was carefully titrated to ensure that the reactions were in the exponential phase. Reaction products were analysed on $1.5 \%$ agarose gels in the presence of ethidium bromide $(250 \mu \mathrm{g} / \mathrm{l})$, and a digital image of each gel was captured using a gel documentation system (Bio-Rad Laboratories, Inc., Hemel Hempstead, Herts, UK).

Chondrocyte number, proliferation, differentiation and matrix production

Dex and Pred (Sigma) were added to the cells at a final concentration of $10^{-8} \mathrm{M}, 10^{-7} \mathrm{M}$ and $10^{-6} \mathrm{M}$, in $0 \cdot 01 \%$ ethanol and compared with control cultures which 
contained $0.01 \%$ ethanol only. Collagen type II and collagen type $\mathrm{X}$ expression was first noted at 10 and 15 days respectively. The GC were added from day 6 or day 11 for the 4 days leading up to the expression of these two chondrocyte phenotypic markers.

Cell layers were rinsed with phosphate buffered saline (PBS) and lysed with $0.9 \% \mathrm{NaCl}$ and $0 \cdot 2 \%$ Triton X-100 and centrifuged at $12000 \mathrm{~g}$ for $15 \mathrm{~min}$ at $4{ }^{\circ} \mathrm{C}$. The supernatant was assayed for protein content and alkaline phosphatase (ALP) activity as a measure of cell number and chondrocyte differentiation respectively. The protein content of the supernatant was measured using the BioRad protein assay reagent (Bio-Rad Laboratories) based on the Bradford dye binding procedure, and gamma globulin was used as standard (Farquharson et al. 1995). Enzyme activity was determined by measuring the cleavage of $10 \mathrm{mM}$ p-nitrophenyl phosphate (pNPP) at $410 \mathrm{~nm}$. Total ALP activity was expressed as nmoles pNPP hydrolysed/ $\mathrm{min} / \mathrm{mg}$ protein (Farquharson et al. 1999). The rate of chondrocyte proliferation was assessed by incubating the chondrocytes with $0 \cdot 2 \mu \mathrm{Ci} / \mathrm{ml}\left[{ }^{3} \mathrm{H}\right]$ thymidine $(37 \mathrm{MBq} /$ $\mathrm{ml}$; Amersham Pharmacia Biotech, Little Chalfont, Bucks, UK) for the last $18 \mathrm{~h}$ of the culture period and the amount of radioactivity incorporated into trichloroacetic acidinsoluble precipitates measured (Farquharson et al. 1999). Proteoglycan synthesis was evaluated by staining with Alcian Blue as previously described (Shukunami et al. 1997). In brief, cells were washed twice with PBS, fixed in 95\% methanol for $20 \mathrm{~min}$ and stained with 1\% Alcian Blue $8 \mathrm{GX}$ (Sigma) in $0.1 \mathrm{M} \mathrm{HCl}$ overnight and rinsed with distilled water. Alcian Blue-stained cultures were extracted with $1 \mathrm{ml} 6 \mathrm{M}$ guanidine- $\mathrm{HCl}$ for $6 \mathrm{~h}$ at room temperature and the optical density (O.D.) was measured at $630 \mathrm{~nm}$ using a Jenway 6105 spectrophotometer.

\section{Apoptosis}

Apoptosis of the cells was measured by two complementary methods: (1) APOPercentage Apoptosis assay, (Biocolor Ltd, Belfast, N Ireland), which quantifies dye uptake by apoptotic cells only after the translocation of phosphatidylserine to the outer surface of the cell membrane (Fadok et al. 1992) and (2) Nucleosome ELISA kit (Oncogene Research Products, Nottingham, Notts, UK), which allows the quantification of apoptotic cells in vitro by DNA affinity-mediated capture of free nucleosomes followed by their anti-histone-facilitated detection. Both kits were used according to the manufacturers' instructions. Dex and Pred at concentrations of $10^{-8} \mathrm{M}, 10^{-7} \mathrm{M}$ and $10^{-6} \mathrm{M}$ were added to the cell cultures on day 6 or day 13 for a period of $24 \mathrm{~h}$. As a positive control, cells were incubated as above with $5 \%$ ethanol.

\section{Recovery following GC exposure}

For these experiments, a single concentration of Dex at $10^{-6} \mathrm{M}$ was used as it was noted to have the most potent

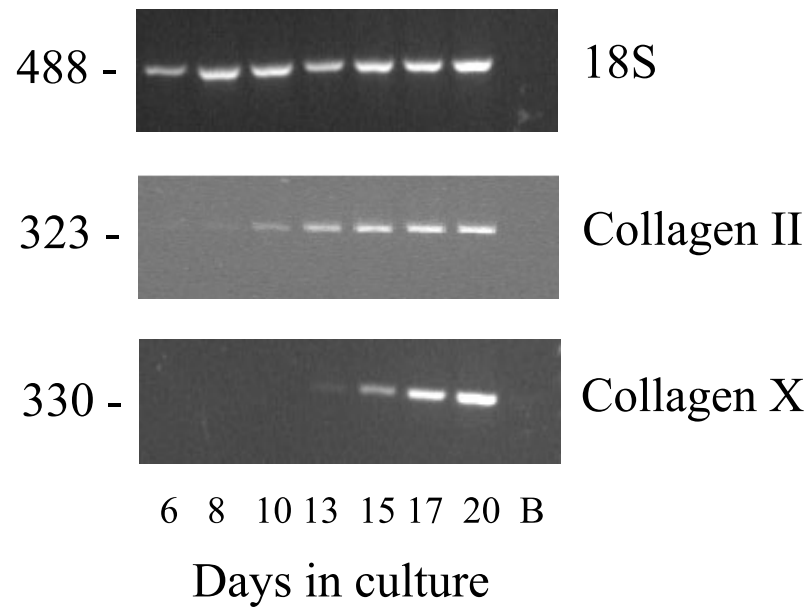

Figure 1 Semiquantative RT-PCR analysis of the expression of chondrocyte marker genes. Collagen type II is expressed from day 10 and collagen type $X$ from day 15 . B, blank.

effects in the above experiments. This dose was added to all cells at confluency (day 6) and subsequently replaced with differentiation medium without Dex after 1, 3, 7 and 10 days. All cultures were maintained for a total of 14 days along with a group that was exposed to Dex for the whole 14 days duration (no recovery period). Additional culture plates of Dex $\left(10^{-6} \mathrm{M}\right)$-treated cells and their respective controls (containing $0.01 \%$ ethanol) were stopped at the allocated time points (days 1, 3, 7 and 10) to assess the impact of Dex prior to the period of recovery. Cell number, ALP activity and proteoglycan content were determined as described above.

\section{Statistical analysis}

All experiments were performed at least twice. Data were analysed by one way analysis of variance. All data are expressed as the mean \pm S.E.M. of four observations within each experiment and statistical analysis was performed using Statview (SAS Institute Inc., Cary, NC, USA; version 5.0.1). $P<0 \cdot 05$ was considered to be significant.

\section{Results}

Temporal expression of chondrocyte phenotype specific markers

Using gene-specific primers, collagen type II expression by the ATDC 5 cells was first noted after 10 days in culture indicating that the differentiation of mesenchymal cells to the chondrocyte phenotype (chondrogenesis) had occurred. Similarly, collagen type X expression was noted from day 15 onwards indicating that terminal differentiation of the chondrocytes occurred from day 10 to day 15 (Fig. 1). This information was used to study the effects of 
Table 2 Effect of Dex and Pred on cellular protein, proteoglycans and alkaline phosphatase activity during chondrogenesis and terminal differentiation. All data are expressed as means \pm S.E.M.

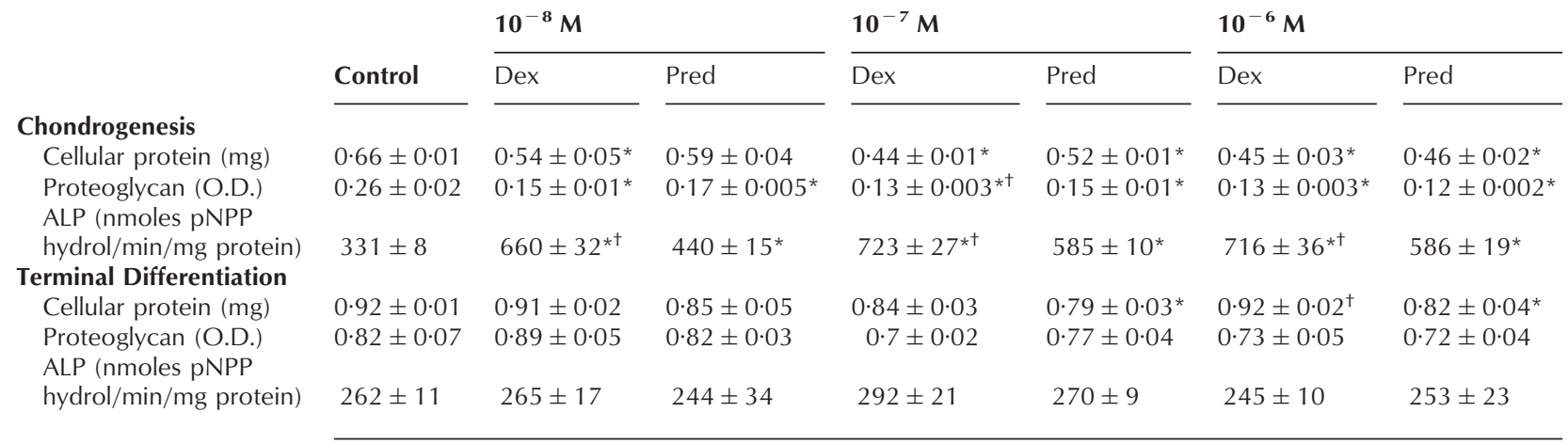

${ }^{*} P<0.05$ compared with control cultures; ${ }^{\dagger} P<0.05$ Dex cultures compared with equivalent dose of Pred.

Dex and Pred during the periods leading up to the expression of these maturation markers.

\section{Effects of GC on cell number and proliferation}

In comparison with control cultures the addition of Dex and Pred to cells during the chondrogenic period (days 6-10) caused a significant reduction in cell number as indicated by cell protein data (Table 2 ). The reduction in cell number from control values for the Dex concentrations tested were: $10^{-8} \mathrm{M}, 18 \cdot 2 \% ; 10^{-7} \mathrm{M}, 33 \cdot 3 \%$; and $10^{-6} \mathrm{M}, 31 \cdot 8 \%(P<0 \cdot 05)$. The apparent plateau noted at $10^{-7} \mathrm{M}$ for Dex was not seen with Pred, where a dosedependent reduction was observed over the three concentrations tested: $10^{-8} \mathrm{M}, 10 \cdot 6 \%$ (not significant); $10^{-7} \mathrm{M}$, $21 \cdot 2 \%(P<0 \cdot 05)$; and $10^{-6} \mathrm{M}, 30 \cdot 3 \%(P<0 \cdot 05)$. The mean reduction in cell number over the three concentrations was 28\% with Dex and 20\% with Pred.

The effect of Dex and Pred on $\left[{ }^{3} \mathrm{H}\right]$ thymidine uptake during the chondrogenesis period is shown in Fig. 2. Both GC caused a significant concentration-dependent decrease in cell proliferation from control values - Dex: $10^{-8} \mathrm{M}$, $11.7 \% ; 10^{-7} \mathrm{M}, 33 \cdot 8 \%$; and $10^{-6} \mathrm{M}, 36 \cdot 6 \%$; Pred: $10^{-8} \mathrm{M}$, $9 \cdot 6 \% ; 10^{-7} \mathrm{M}, 24 \cdot 7 \%$; and $10^{-6} \mathrm{M}, 37 \%(P<0 \cdot 05)$. As was noted for cell number, the apparent plateau noted at $10^{-7} \mathrm{M}$ for Dex was not seen with Pred, where a dose-dependent decrease was observed over the three concentrations tested. The mean reduction over the three concentrations for Dex and Pred was 27\% and 24\% respectively. Dex at $10^{-7} \mathrm{M}$ was significantly more antiproliferative than Pred at $10^{-7} \mathrm{M}(P<0 \cdot 05)$.

During the terminal differentiation phase (days 10-15) Dex did not significantly alter cell numbers when compared with control values (Table 2), whereas Pred caused a significant reduction $(P<0 \cdot 05)$ at both $10^{-7} \mathrm{M}(14 \cdot 1 \%)$ and $10^{-6} \mathrm{M}(10 \cdot 9 \%)$. The cell proliferation rate in control cultures was sixfold less during the terminal differentiation phase than during the chondrogenic stage and the addition of GC led to a significant suppression of proliferation with Dex at $10^{-8} \mathrm{M}(40 \cdot 9 \%), 10^{-7} \mathrm{M}(24 \cdot 1 \%)$ and $10^{-6} \mathrm{M}$ $(40 \cdot 3 \%)$ whereas a reduction in proliferation by Pred was noted at $10^{-8} \mathrm{M}(26 \cdot 3 \%)$, with a rise in proliferation at $10^{-6} \mathrm{M}(21 \cdot 6 \%, P<0 \cdot 05)$ (Fig. 2).

\section{Effects of GC on proteoglycan production}

In comparison with control cultures during the chondrogenesis period, there was a concentration-dependent reduction in proteoglycan synthesis ranging from 42 to 50\% with Dex and 35 to 54\% with Pred (Table 2). An apparent plateau was noted at $10^{-7} \mathrm{M}$ for Dex which was not seen with Pred, where a dose-dependent reduction was observed over the three concentrations tested.

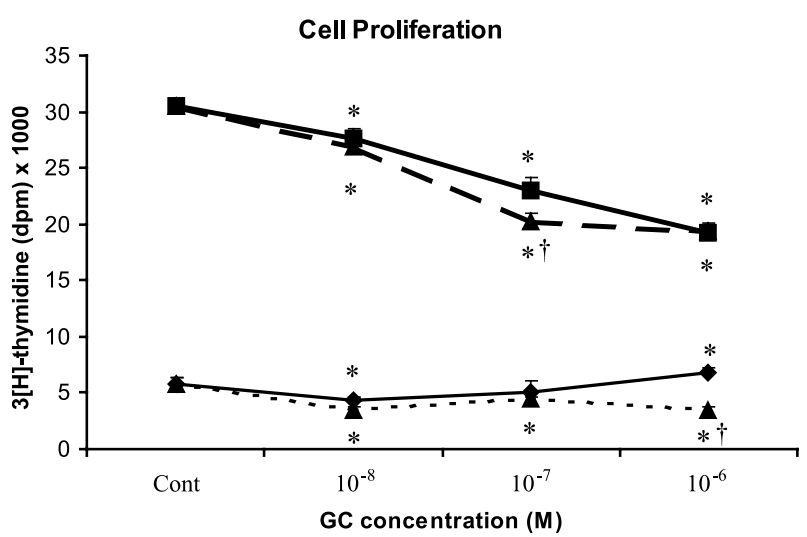

Figure 2 Effect of Dex and Pred on cell proliferation as assessed by $\left[{ }^{3} \mathrm{H}\right]$ thymidine uptake during chondrogenesis and terminal differentiation phases. Effect of Dex on chondrogenesis $(\boldsymbol{\Lambda}$ and long dashed lines); effect of Dex on terminal differentiation ( $\boldsymbol{\Lambda}$ and short dashed lines); effect of Pred on chondrogenesis ( $\mathbf{\square}$ and solid line); effect of Pred on terminal differentiation ( and solid line). All data are expressed as means \pm S.E.M. ${ }^{*} P<0 \cdot 05$ compared with control (Cont); $\uparrow P<0.05$ significance level between Dex and equivalent dose of Pred. 
Comparing Dex and Pred at equivalent concentrations, Dex at $10^{-7} \mathrm{M}$ caused a significantly greater fall in proteoglycans than Pred at $10^{-7} \mathrm{M}(P<0 \cdot 05)$ (Table 2). Over the three concentrations, Dex caused a mean reduction in proteoglycan synthesis of $47 \%$ compared with $43 \%$ with Pred. No significant differences were noted during terminal differentiation.

\section{Effect of GC on chondrocyte differentiation}

The effect of GC on terminal chondrocyte differentiation as assessed by ALP activity is shown in Table 2. During chondrogenesis, enzyme activity in comparison with control values was significantly increased with both Dex: $10^{-8} \mathrm{M}, 83 \% ; 10^{-7} \mathrm{M}, 118 \%$; and $10^{-6} \mathrm{M}, 116 \%$ and Pred: $10^{-8} \mathrm{M}, 39 \% ; 10^{-7} \mathrm{M}, 77 \%$; and $10^{-6} \mathrm{M}, 77 \%(P<0 \cdot 05)$. The mean elevations in ALP with all concentrations of Dex and Pred were 106\% and 62\% respectively and at equimolar concentrations of GC, Dex caused significantly larger increases in ALP than Pred. No significant differences in ALP activity were noted during the terminal differentiation phase.

\section{Effects on apoptosis}

Using the APOPercentage Apoptosis assay the number of apoptotic cells was higher in the terminally differentiating chondrocytes in comparison with cultures in the chondrogenesis phase. No evidence was detected for an effect of Dex and Pred on apoptosis during the chondrogenesis phase (Fig. 3a), however during terminal differentiation all Dex concentrations, and Pred at $10^{-6} \mathrm{M}$ caused a significant decrease in apoptotic cell numbers $(P<0 \cdot 05)$ (Fig. 3b). Ethanol acted as a positive control and caused an elevation in apoptosis at both developmental phases $(P<0 \cdot 05)$. These data were confirmed with the use of the nucleosome ELISA kit (results not shown).

\section{Recovery following GC exposure}

Exposure of the ATDC5 cells to Dex for one or more days resulted in lower cell numbers on day 14. These differences, however, did not reach statistical significance unless the cells were exposed to Dex for all 14 days $(P<0 \cdot 05)$ (Fig. $4 \mathrm{a}$ and $\mathrm{b}$ ). There was a significant reduction in proteoglycan content after 7, 10 and 14 days of GC exposure (Fig. 4c). After the recovery period (Fig. 4d), all Dex-exposed cells showed a significant reduction in proteoglycan content $(P<0 \cdot 05)$. ALP activity was increased after Dex treatment at days 7, 10 and 14 compared with control cultures but this increase was statistically significant only after 7 (65\%) and 14 (148\%) days of exposure (Fig. 4e). After the recovery period (Fig. 4f) ALP remained significantly elevated from day 10 $(P<0 \cdot 05)$.

\section{Discussion}

GC are known to exert effects on many physiological systems and can retard growth in children (Loeb 1976). While they may do this by altering GH secretion or GH sensitivity (Luo \& Murphy 1989, Lima et al. 1993, Devesa et al. 1995), it is very likely that they may also exert direct effects on growth plate chondrocytes (Baron et al. 1992). In vivo studies in rats and in vitro studies using primary cultured rat epiphyseal chondrocytes show a downregulation of $\mathrm{GH}$ receptor mRNA expression after GC treatment as well as an inhibition of IGF-I production and secretion into the culture medium (Gabriellsson et al. 1995, Jux et al. 1998). However, Heinrichs et al. (1994) reported an increase in $\mathrm{GH}$ receptor gene expression levels after treatment of rabbits with Dex. A reduction in rat growth cartilage width after GC treatment has also been observed and these authors have suggested that this is a likely consequence of the lower chondrocyte proliferation rate and increased hypertrophic chondrocytes apoptosis (Silvestrini et al. 2000).

Studies using rat chondrocyte cultures showed that Dex and Pred reduced both cell proliferation and colony formation and also that Dex was more potent than Pred at equimolar concentrations (Dearden et al. 1986, Robson et al. 1998). This culture data is in accord with in vivo observations where Dex appears to be more potent than Pred at causing impairment of normal bone growth (Strauss et al. 2001, Ahmed et al. 2002).

Our present experiments used the ATDC5 chondrocyte cell line, which has less phenotypic diversity than cultures containing a heterogeneous population of primary chondrocytes (Robson et al. 1998, Koedam et al. 2000). Furthermore, it allows the study of two critical events during cartilage formation: the early differentiation of committed mesenchymal cells into chondrocytes (chondrogenesis) and the terminal differentiation of proliferating to hypertrophic chondrocytes (Cancedda et al. 1995). Cell numbers were reduced by both Dex and Pred during the chondrogenesis period, but little effect of either GC was noted during the terminal differentiation period. Cell numbers may be reduced by GC by mechanisms such as loss of proliferative activity, increased apoptosis and cytostasis. Our present data strongly support the proposal that loss of proliferative activity is, at least in part, responsible for the decrease in chondrocyte numbers by GC treatment. We found no evidence of increased apoptosis, which is in accordance with Mehls et al. (2001). In the growth plate it is well recognised that apoptotic chondrocytes are most prevalent in the terminally differentiated zone (Ohyama et al. 1997) and this is also reflected in the ATDC5 cell line as shown in the present study. Interestingly, GC reduced apoptosis in the terminally differentiated cells whilst having no effect on the chondrogenesis phenotype, suggesting that GC control of chondrocyte apoptosis is phenotype dependent. This observation 
a)
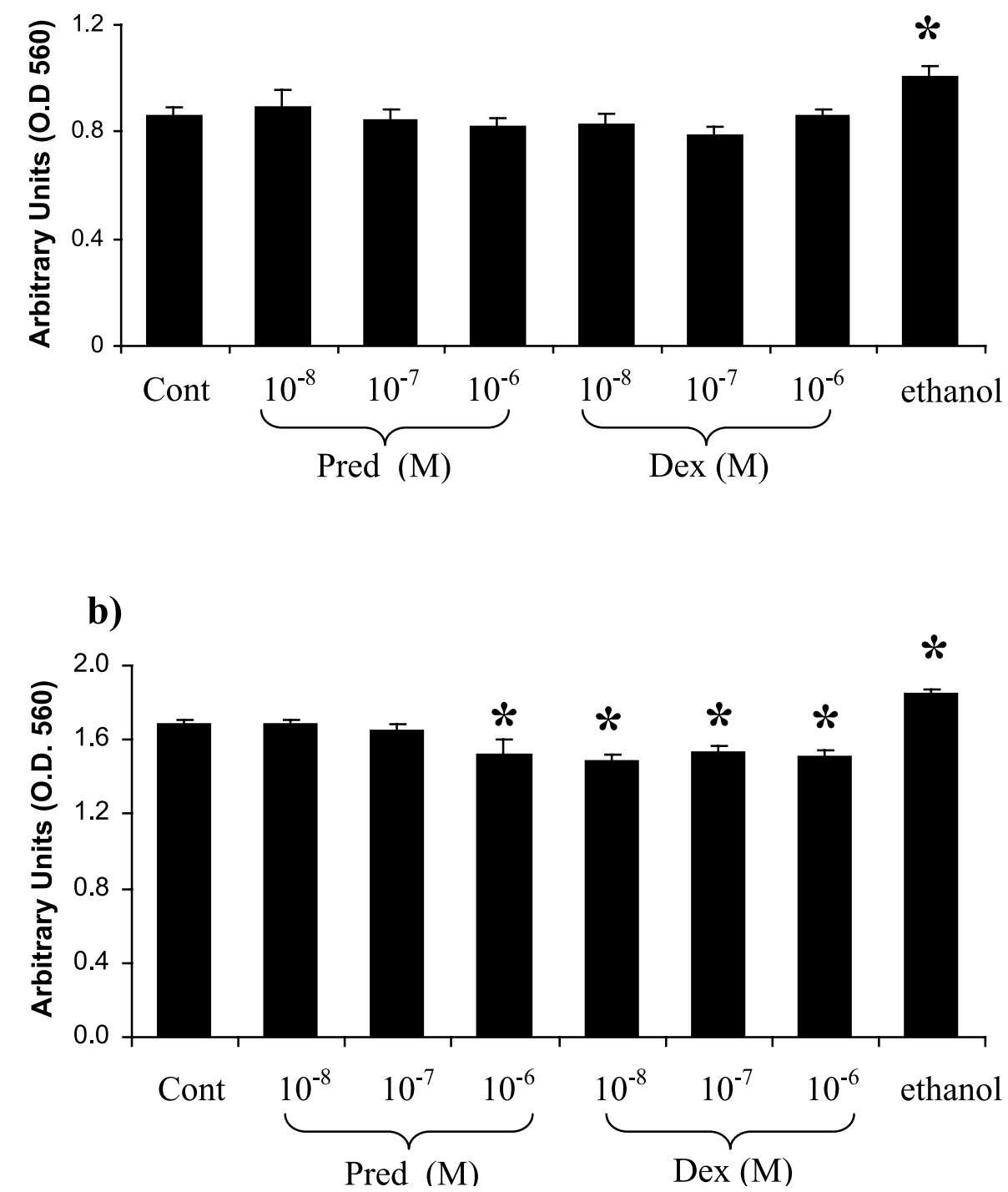

Figure 3 Effect of Dex and Pred treatment for $24 \mathrm{~h}$ on the incidence of apoptosis during (a) chondrogenesis and (b) terminal differentiation. All data are expressed as means \pm S.E.M. ${ }^{*} P<0 \cdot 05$ compared with control (Cont). No effects of the GC were observed during the chondrogenesis phase whereas all concentrations of Dex, and Pred at $10^{-6} \mathrm{M}$, caused a significant reduction in apoptosis during terminal differentiation. Ethanol (5\%) caused a significant elevation in apoptosis at both developmental time points.

requires further study. Cell proliferation rates and cell numbers were more greatly affected by Dex and Pred during the chondrogenesis period when the chondrocytes were rapidly proliferating. These results extend the data from cultures containing chondrocytes of various maturational phenotypes (Robson et al. 1998) and are also in agreement with studies on other bone cell types which indicate that Dex was more potent than Pred in reducing osteoblast cell number and DNA synthesis (Kasperk et al. 1995, Davies et al. 2002). Davies and colleagues (2002) also reported that osteoblast precursor cells (HCC1) were more chemosensitive to Dex than fully differentiated osteoblasts and together with our present data suggest that in bone cells, GC exert their maximum effect at the cell precursor stage. Over the three concentrations, Dex was also more potent than Pred as it caused a $44 \%$ greater increase in ALP activity and greater reductions in proteoglycan synthesis, cell number and cell proliferation. Annefeld (1992) also showed that Dex treatment in rats results in inhibition of both chondrocyte proliferation and 


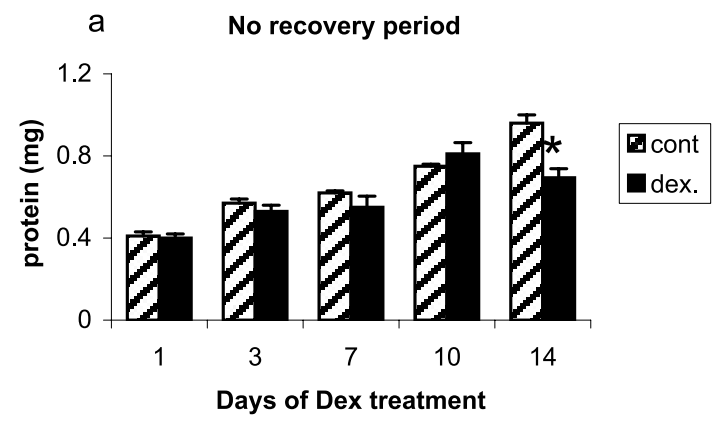

C

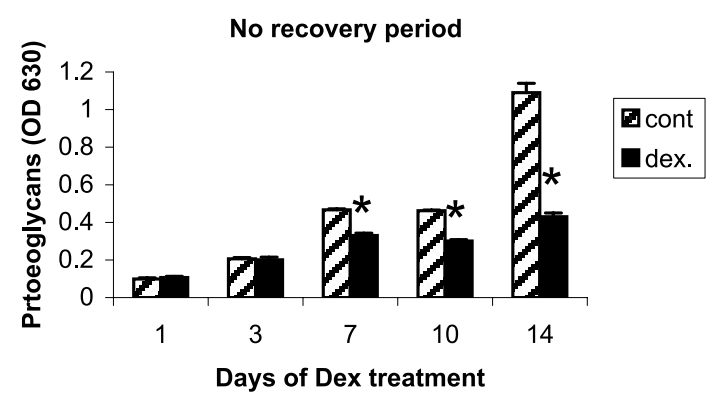

e

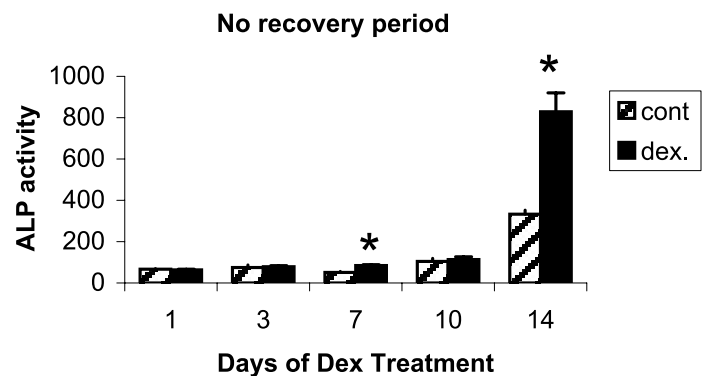

b

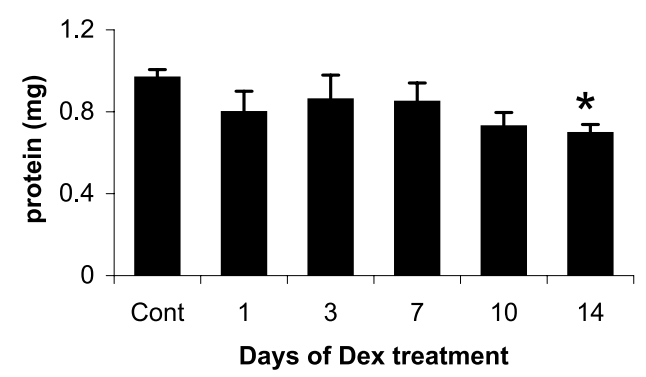

d

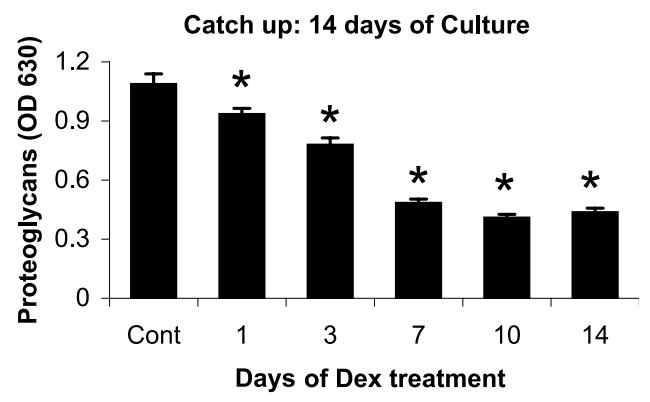

$f \quad$ Catch up: 14 days of culture

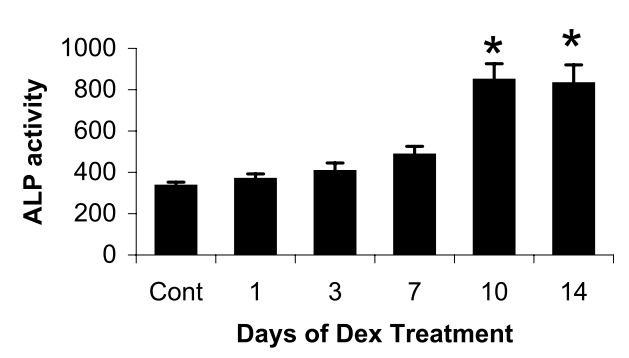

Figure 4 Effect of $10^{-6} \mathrm{M}$ Dex on protein ( $a$ and b), proteoglycans (c and d) and ALP activity (e and f) either after a period of no recovery $(\mathrm{a}, \mathrm{c}, \mathrm{e})$ or where the Dex-treated cells were allowed to recover and were assayed at 14 days (b, d, f). (a) The cell number increased with time in culture. The only significant reduction was after 14 days Dex treatment $(P<0 \cdot 05)$. (b) Protein was reduced at all time points, but this was only significant at day $14(P<0 \cdot 05)$. (c) Proteoglycan levels were elevated with time in the control group, but there was a significant reduction in proteoglycans $(P<0 \cdot 05)$ from day 7 to day 14 in the Dex-treated group as compared with their controls. (d) A significant reduction in proteoglycan content occurred after 1 day Dex treatment $(P<0 \cdot 05)$ and this was more pronounced with longer periods of treatment. (e) There was a gradual elevation in ALP activity (nmoles pNPP hydrolysed/min/mg protein) at each time point with a significant elevation above the respective control at days 7 and 14. (f) After the recovery period, ALP activity remained elevated and reached significance at days 10 and $14(P<0 \cdot 05)$. Cont, control.

cartilage matrix production. The pro-differentiating effects of Dex are in agreement with studies using costochondral cultures, in which Dex promoted ALP activity (Schwartz et al. 1995). However, the results are at variance with other studies where Dex lowered enzyme activity in prehypertrophic chondrocytes but had minimal effects on hypertrophic or mineralising chondrocytes (Robson et al. 2001). Although these results are in contrast to those presented here, they do substantiate our own observations and those of others that the response of chondrocytes to 
Dex is dependent on their stage of differentiation (Yasuda et al. 1995).

In growth failure, amelioration of the growth retarding insult results in a period of supranormal linear growth described as catch-up growth (Prader et al. 1963). Two underlying mechanisms for this phenomenon have been suggested - a neuroendocrine model which adjusts the growth rate to an age appropriate set point, and a local mechanism intrinsic to the growth plate (Prader et al. 1963, Baron et al. 1994). Baron et al. (1994) demonstrated a 77\% reduction in the growth rate of 5-week-old rabbit limbs that had Dex infused into the proximal tibial growth plate. Following cessation of Dex, catch-up growth was observed in the affected growth plate and not in the contralateral tibia. It is postulated that this is due partly to a delay in growth plate senescence by Dex (Gafni et al. 2001).

The ATDC5 cell line allowed us to study this recovery phenomenon in greater detail. No differences were observed in proteoglycan content in the culture plates stopped prior to recovery at 24 and $72 \mathrm{~h}$ of treatment. However, after the recovery period a reduction in proteoglycans was apparent at all treatment lengths. This would indicate that Dex-induced suppression may take some time to manifest itself even though the stimulus for suppression has been removed. Longer treatments with Dex of 7 and 10 days duration showed unchanged levels of proteoglycans compared with the 14-day treated group and indicates that within the timescale of this experiment the ability to recover after 7 days of Dex treatment was irreversible. Longer periods of recovery allowed the ALP activity to be suppressed towards control levels, although after 10 days there was no further recovery noted as compared with the 14-day Dex-treated group. It cannot be ruled out, however, that longer periods of recovery could result in suppression of ALP activity back to control levels. It is possible that catch-up growth is never complete and merely falls below the statistical detection limit of a study (Silverstein et al. 1997).

In conclusion, Dex and Pred reduce cell number, cell proliferation and proteoglycan content whilst stimulating chondrocyte differentiation. The GC have maximal effects during chondrogenesis with minimal effects during terminal differentiation. The ability to recover is related to the length of Dex exposure and possibly the chondrocyte phenotype. Our studies suggest that the potential for recovery of different events of the chondrocyte life cycle may vary. Our findings in the ATDC5 cell line will allow a more focussed approach towards studying the mechanisms underlying GC-induced growth retardation as well as investigating the potential benefit of growth-promoting therapy.

\section{Acknowledgements}

The study was generously supported by the Chief Scientist Office of Scotland, Novo Nordisk UK Ltd, the Biotech- nology and Biological Sciences Research Council and a research award by the British Society of Paediatric Endocrinology and Diabetes. The authors are also grateful to Dr Brian Houston for help with the PCR analysis and to Dr Bronwen Evans for access to her unpublished data.

\section{References}

Ahmed SF, Wallace WH, Crofton PM, Wardburgh B, Magowan R \& Kelnar CJ 1999 Short-term changes in lower leg length in children treated for acute lymphoblastic leukaemia. Journal of Pediatric Endocrinology and Metabolism 12 75-80.

Ahmed SF, Tucker P, Mushtaq T, Wallace AM, Williams DM \& Hughes IA 2002 Linear growth and bone turnover in children randomized to receive prednisolone or dexamethasone. Clinical Endocrinology 57 185-191.

Annefeld M 1992 Changes in rat epiphyseal cartilage after treatment with dexamethasone and glycosaminoglycan-peptide complex. Pathology, Research and Practice 188 649-652.

Atsumi T, Miwa Y, Kimata K \& Ikawa Y 1990 A chondrogenic cell line derived from a differentiating culture of AT805 teratocarcinoma cells. Cell Differentiation and Development $\mathbf{3 0}$ 109-116.

Baron J, Huang Z, Oerter KE, Bacher JD \& Cutler GB 1992 Dexamethasone acts locally to inhibit longitudinal bone growth in rabbits. American Journal of Physiology 263 E489-E492.

Baron J, Klein KO, Colli MJ, Yanovski JA, Novosad JA, Bacher JD \& Cutler GB Jr 1994 Catch-up growth after glucocorticoid excess: a mechanism intrinsic to the growth plate. Endocrinology 135 1367-1371.

Blodget FM, Burgin L, Iezzoni D, Gribetz D \& Talbot NB 1956 Effects of prolonged cortisone therapy on the statural growth, skeletal maturation and metabolic status of children. New England Journal of Medicine 254 636-641.

Cancedda R, Descalzi Cancedda F \& Castognola P 1995 Chondrocyte differentiation. International Review of Cytology 159 265-358.

Crilly R, Cawood M, Marshall DH \& Nordin BE 1978 Hormonal status in normal, osteoporotic and corticosteroid-treated postmenopausal women. Journal of the Royal Society of Medicine $\mathbf{7 1}$ 733-736.

Crofton PM, Ahmed SF, Wade JC, Stephen R, Elmlinger MW, Ranke MB, Kelnar CJ \& Wallace WH 1998 Effects of intensive chemotherapy on bone and collagen turnover and the growth hormone axis in children with acute lymphoblastic leukemia. Journal of Clinical Endocrinology and Metabolism 83 3121-3129.

Davies JH, Evans BAJ, Jenney MEM \& Gregory JW 2002 In vitro effects of chemotherapeutic agents on human osteoblast-like cells. Calcified Tissue International 70 408-415.

Dearden LC, Mosier HD Jr, Brundage M, Thai C \& Jansons R 1986 The effects of different steroids on costal and epiphyseal cartilage of fetal and adult rats. Cell and Tissue Research 246 401-412.

Devesa J, Barros MG, Gondar M, Tresguerres JA \& Arce V 1995 Regulation of hypothalamic somatostatin by glucocorticoids. Journal of Steroid Biochemistry and Molecular Biology 53 277-282.

Fadok VA, Voelker DR, Campbell PA, Cohen JJ, Bratton DL \& Henson PM 1992 Exposure of phosphatidylserine on the surface of apoptotic lymphocytes triggers specific recognition and removal by macrophages. Journal of Immunology 148 2207-2216.

Farquharson C, Berry JL, Mawer EB, Seawright E \& Whitehead CC 1995 Regulators of chondrocyte differentiation in tibial dyschondroplasia: an in vivo and in vitro study. Bone 17 279-286.

Farquharson C, Lester D, Seawright E, Jefferies D \& Houston B 1999 Microtubules are potential regulators of growth-plate chondrocyte differentiation and hypertrophy. Bone 25 405-412.

Gabriellsson BG, Carmignac DF, Flavell DM \& Robinson IC 1995 Steroid regulation of growth hormone $(\mathrm{GH})$ receptor and 
GH-binding protein messenger ribonucleic acids in the rat. Endocrinology 136 209-217.

Gafni RI, Weise M, Robrecht DT, Meyers JL, Barnes KM, De-Levi S \& Baron J 2001 Catch-up growth is associated with delayed senescence of the growth plate in rabbits. Pediatric Research $\mathbf{5 0}$ 618-623.

Green H, Morikawa M \& Nixon T 1985 A dual effector theory of growth hormone action. Differentiation 29 195-198.

Heinrichs C, Yanovski JA, Roth AH, Yu YM, Domene HM, Yano K, Cutler GB Jr \& Baron J 1994 Dexamethasone increases growth hormone receptor messenger ribonucleic acid levels in liver and growth plate. Endocrinology 135 1113-1118.

Houston B, Seawright E, Jefferies D, Hoogland E, Lester D, Whitehead CC \& Farquharson C 1999 Identification and cloning of a novel phosphatase expressed at high levels in differentiating growth plate chondrocytes. Biochimica et Biophysica Acta 1448 500-506.

Isaksson OG, Ohlsson C, Nilsson A, Isgaard J \& Lindahl A 1991 Regulation of cartilage growth by growth hormone and insulin-like growth factor I. Pediatric Nephrology 5 451-453.

Jabs K, Sullivan EK, Avner ED \& Harmon WE 1996 Alternate-day steroid dosing improves growth without adversely affecting graft survival or long-term graft function. A report of the North American Pediatric Renal Transplant Cooperative Study. Transplantation 61 31-36.

Jefferies D, Botman M, Farquharson C, Lester D, Whitehead CC, Thorp BH \& Houston B 1998 Cloning differentially regulated genes from chondrocytes using agarose gel differential display. Biochimica et Biophysica Acta 1396 237-241.

Jefferies D, Houston B, Lester D, Whitehead CC, Thorp BH, Botman M \& Farquharson C 2000 Expression patterns of chondrocyte genes cloned by differential display in tibial dyschondroplasia. Biochimica et Biophysica Acta 1501 180-188.

Jux C, Leiber K, Hugel U, Blum W, Ohlsson C, Klaus G \& Mehls O 1998 Dexamethasone impairs growth hormone (GH)-stimulated growth by suppression of local insulin-like growth factor (IGF)-I production and expression of GH- and IGF-I-receptor in cultured rat chondrocytes. Endocrinology 139 3296-3305.

Kasperk C, Schnieder U, Sommer U, Niethard F \& Zeigler R 1995 Differential effects of glucocorticoids on human osteoblastic cell metabolism in vitro. Calcified Tissue International 57 120-126.

Koedam JA, Hoogerbrugge CM \& Van Buul-Offers SC 2000 Differential regulation of IGF-binding proteins in rabbit costal chondrocytes by IGF-I and dexamethasone. Journal of Endocrinology $165557-567$.

Lima L, Arce V, Diaz MJ, Tresguerres JA \& Devesa J 1993 Glucocorticoids may inhibit growth hormone release by enhancing beta-adrenergic responsiveness in hypothalamic somatostatin neurons. Journal of Clinical Endocrinology and Metabolism 76 439-444.

Loeb JN 1976 Corticosteroids and growth. New England Journal of Medicine 295 547-552.

Luo JM \& Murphy LJ 1989 Dexamethasone inhibits growth hormone induction of insulin-like growth factor-I (IGF-I) messenger ribonucleic acid (mRNA) in hypophysectomized rats and reduces IGF-I mRNA abundance in the intact rat. Endocrinology 125 $165-171$.
Mehls O, Rainer H, Homme M, Kiepe D \& Klaus G 2001 The interaction of glucocorticoids with the growth hormone-insulin-like growth factor axis and its effects on growth plate chondrocytes and bone cells. Journal of Paediatric Endocrinology and Metabolism 14 1475-1482.

Ohyama K, Farquharson C, Whitehead CC \& Shapiro IM 1997 Further observations on programmed cell death in the epiphyseal growth plate: comparison of normal and dyschondroplastic epiphyses. Journal of Bone and Mineral Research 12 1647-1656.

Prader A, Tanner JM \& Harnack GA 1963 Catch-up growth following illness or starvation. Journal of Pediatrics 62 646-659.

Robson H, Anderson E, Eden OB, Isaksson O \& Shalet S 1998 Chemotherapeutic agents used in the treatment of childhood malignancies have direct effects on growth plate chondrocyte proliferation. Journal of Endocrinology 157 225-235.

Robson H, Seibler T, Shalet SM \& Williams GR 2001 Glucocorticoids and thyroid hormone control growth plate chondrocyte differentiation by different mechanisms. Proceedings of the 20th Joint Meeting of the British Endocrine Societies. Endocrine Abstracts $1 \mathrm{P} 3$.

Schwartz Z, Hancock RH, Dean DD, Brooks BP, Gomez R, Boskey AL, Balian G \& Boyan BD 1995 Dexamethasone promotes von Kossa-positive nodule formation and increases alkaline phosphatase activity in costochondral chondrocyte cultures. Endocrine $\mathbf{3}$ 351-360.

Shukunami C, Ishizeki K, Atsumi T, Ohta Y, Suzuki F \& Hiraki Y 1997 Cellular hypertrophy and calcification of embryonal carcinoma-derived chondrogenic cell line ATDC5 in vitro. Journal of Bone and Mineral Research 12 1174-1188.

Silverstein MD, Yunginger JW, Reed CE, Petterson T, Zimmerman D, Li JT \& O'Fallon WM 1997 Attained adult height after childhood asthma: effect of glucocorticoid therapy. Journal of Allergy and Clinical Immunology 99 466-474.

Silvestrini G, Ballanti P, Patacchioli FR, Mocetti P, Di Grezia R, Wedard BM, Angelucci L \& Bonucci E 2000 Evaluation of apoptosis and the glucocorticoid receptor in the cartilage growth plate and metaphyseal bone cells of rats after high-dose treatment with corticosterone. Bone 26 33-42.

Strauss AJ, Su JT, Dalton VM, Gelber RD, Sallan SE \& Silverman LB 2001 Bony morbidity in children treated for acute lymphoblastic leukemia. Journal of Clinical Oncology 19 3066-3072.

Unterman TG \& Phillips LS 1985 Glucocorticoid effects on somatomedins and somatomedin inhibitors. Journal of Clinical Endocrinology and Metabolism 61 618-626.

Warner J 1995 Review of prescribed treatment for children with asthma in 1990. British Medical Journal 311 663-666.

Yasuda T, Shimizu K \& Nakamura T 1995 Effects of dexamethasone on terminal differentiation and matrix mineralisation in rat growth plate chondrocyte cultures. Biomedical Research 16 319-325.

Received in final form 23 July 2002 Accepted 13 August 2002 